\title{
Proximate composition, bio-chemical and microbial quality of pet food prepared from chicken byproducts by incorporating cauliflower wastes
}

\author{
N. Brindha* and V. Appa Rao \\ Department of Livestock Product Technology, Madras Veterinary College, Chennai-600 007 (Tamil Nadu ), INDIA \\ *Corresponding author. E-mail: brindha26887@gmail.com
}

Received:October 15, 2016; Revised received: January 31, 2017; Accepted: April 15, 2017

\begin{abstract}
A study was under taken on preparation of pet food from chicken head (20\%), feet meal $(15 \%)$ and cauliflower waste meal $(10 \%)$. The proximate composition, chemical and microbial qualities were analysed. The proximate composition (\%) viz., crude protein, ether extract, crude fibre, total ash, nitrogen free extract and metabolizable energy ( $\mathrm{K} \mathrm{Cal} / 100 \mathrm{~g})$ of pet food on dry matter basis were $26.63,18.52,1.38,10.29,43.17$ and 422.28 , respectively. The thiobarbituric acid from 0.46 to $2.52 \mathrm{mg} \mathrm{MA} / \mathrm{kg}$, tyrosine value 35.53 to $77.36 \mathrm{mg} / 100 \mathrm{~g}$ and total viable count log 3.46 to $5.90 \mathrm{cfu} / \mathrm{g}$ were increasing significantly $(P<0.01)$ and yeast and mould count was not detected up to 50 days of storage period. The pets were fed with prepared pet food and evaluated by pet owner gave score for appearance, consistency, odour which were in normal range and overall acceptability was good.
\end{abstract}

Keywords: Chicken byproducts, Chemical and microbial quality, Pet food, Proximate composition

\section{INTRODUCTION}

Pets play a vital role in day to day activities and act as a family member both in rural and urban family. Feeding of pet dogs was very composite in the last few decades due to unavailability of a complex balanced nutritious food. Due to rapid urbanization and globalization along with foreign collaborative partnerships, pet food industry has attempted to produce nutritionally balanced pet foods. In India, the pet food market is a rapidly growing market which grows at an average rate of $10-15 \%$ in recent years. Traditionally the Indians are consuming fresh poultry meat rather than processed poultry food products. So poultry retail shops which give fresh poultry meat end up in producing lot of inedible waste which includes head, feet, feather, intestine and blood. R. P. Singh, (2012) stated that the process of converting poultry slaughter by-products, constituting about $25-35 \%$ of live weight of poultry into a highly palatable nutritious pet food has been developed with a shelf life of six months at ambient temperature $\left(26^{\circ} \mathrm{C}\right)$. Cauliflower is one of the most important winter vegetables of India. According to FAOSTAT (2011) production level of cabbage and other brassica vegetables in India was 7.94 million tonnes. India being a developing country, it is the second largest producers of cauliflower in the world. Abul-Fadl, (2012) concluded that the utilization of white cauliflower by-products flour up to $7.5 \%$ as fat replacers in production of meat products would result in lowering the cost of product and also improve the nutritional (protein, minerals, antioxidant compounds especially phenolic compounds and crude fibre), physicochemical and sensory qualities of the product. Unfortunately, cauliflower waste in developing countries like India does not find any significant commercial use, despite containing appreciable amount of proteins and minerals. The feathers are the rich source of keratin, which is difficult to digest. Intestine and blood are the waste which cannot be utilized easily due to high processing cost and time. On the other hand head and feet are the waste which can be easily processed and utilized as raw material for pet food production. To promote the utilization of unconventional raw materials in the preparation of value added completely balanced nutritious pet food, we have undertaken this study to develop pet food from poultry retail shop waste and cauliflower waste.

\section{MATERIALS AND METHODS}

Formulation of pet food: According to the recommendation for nutrients specification given by the Association of American Feed Control Officials (2008) and National Research Council (2006) for the adult dog's maintenance diet, the pet food was prepared by adding $20 \%$ chicken head meal, $15 \%$ chicken feet meal and $10 \%$ cauliflower waste meal. The mixed content was cooked at $121^{\circ} \mathrm{C}$ temperature, $15 \mathrm{lbs}$ pressure for 15 minutes and extruded through a mechanical hand extruder. The extruded material was dried to prepare brownish meaty flavour pet food.

Proximate composition: The proximate composition viz., moisture, protein, fat, total ash, crude fibre and nitrogen free extract were analyzed as per AOAC 
(1995). Crude protein estimation was done in KEL plus Automatic Nitrogen / Protein Estimation System (Model Classic DX) and ether extract estimation was done in SOCS plus (Model SCS 4) Pelican Equipment Pvt. Ltd., Chennai, metabolisable energy was estimated as per the procedure of NRC 2006. Nitrogen free extract was calculated as per Weende's system.

Bio-chemical and microbial analysis of pet food: Thiobarbituric acid number and tyrosine value were estimated as per Strange et al. (1977) with slight modification. The total plate count and yeast and mold count were estimated as per International Commission on Microbiological Specifications for Foods (1986) and American Public Health Association (1984).

Pet food acceptability evaluation: Pet food acceptability evaluation was conducted in 15 dogs. The pet food was fed to the dogs in the presence of owner during their normal feeding time. Observations namely colour, consistency, odour and pet acceptability were made and recoded on a score card by questionnaire method. The range of the score card was kept between 1 and 9 . The questionnaire was prepared as per the guidelines of Ponmani (1997), Karthikeyan (2000, 2004) and Karthik et al (2010) with slight modification.

Statistical analysis: The data obtained from biochemical and microbial examination were analysed for variance (ANOVA) according to Snedecor and Cochran, 1989 using SAS (SPSS version 19.0 for Windows, 1999). Duncan multiple range test was applied when significant difference $(\mathrm{P}<0.05)$ to separate its mean values

\section{RESULTS AND DISCUSSION}

In the present study choosing of chicken head and feet, cruciferous vegetable waste were selected as a raw material for the preparation of pet food and presented in Table 1 and was correlated with the results of

Table 1. Formulation of pet food containing chicken head, feet meal and cauliflower waste meal.

\begin{tabular}{|c|c|c|}
\hline Ingredient & Percentage & Grams \\
\hline White corn flour & 10 & 100 \\
\hline Wheat gluten meal & 10 & 100 \\
\hline Rice flour & 20 & 200 \\
\hline Chicken head meal & 20 & 200 \\
\hline Chicken feet meal & 15 & 150 \\
\hline Beef fat & 10 & 100 \\
\hline Cruciferous vegetable meal & 10 & 100 \\
\hline Calcium carbonate & 2 & 20 \\
\hline Dry yeast & 2 & 20 \\
\hline Iodised salt & 0.5 & 5 \\
\hline Vitamin \& Mineral mix & 0.5 & 5 \\
\hline Total & 100 & $1000 \mathrm{~g}$ \\
\hline Ingredients & & Levels \\
\hline \multicolumn{3}{|l|}{ Vitamins } \\
\hline Vitamin A I.P (as acetate) & & 10000 I.U \\
\hline Cholecalciferol (Vit-D $\left.{ }_{3}\right)$ & & 1000 I.U \\
\hline Thiamine Mononitrate I.P & & $10 \mathrm{mg}$ \\
\hline Riboflavine & & $10 \mathrm{mg}$ \\
\hline Pyridoxine hydrochloride & & $3 \mathrm{mg}$ \\
\hline Cyanocobalamin & & $15 \mathrm{mg}$ \\
\hline Nicotinamide & & $100 \mathrm{mg}$ \\
\hline Calcium pantothenate & & $16.30 \mathrm{mg}$ \\
\hline Ascorbic acid & & $150 \mathrm{mg}$ \\
\hline Alpha tocopheryl acetate & & $25 \mathrm{mg}$ \\
\hline Biotin & & $0.25 \mathrm{mg}$ \\
\hline \multicolumn{3}{|l|}{ Minerals } \\
\hline Tribasic calcium phosphate & & $129 \mathrm{mg}$ \\
\hline Magnesium oxide(light) & & $60 \mathrm{mg}$ \\
\hline Dried ferrous sulphate & & $32.04 \mathrm{mg}$ \\
\hline Manganese sulphate monohydrate & & $2.03 \mathrm{mg}$ \\
\hline Total phosphorus & & $25.8 \mathrm{mg}$ \\
\hline \multicolumn{3}{|l|}{ Trace elements } \\
\hline Copper pentahydrate & & $3.39 \mathrm{mg}$ \\
\hline Zinc sulphate & & $2.2 \mathrm{mg}$ \\
\hline Sodium molybolate dehydrate & & $0.25 \mathrm{mg}$ \\
\hline Sodium borate & & $0.88 \mathrm{mg}$ \\
\hline
\end{tabular}


Table 2. Nutritive composition of pet food (Mean value).

\begin{tabular}{ll}
\hline Parameters & Dry matter basis \\
\hline Moisture (\%) & - \\
Dry matter (\%) & 95.3 \\
Crude protein (\%) & 26.63 \\
Ether extract (\%) & 18.52 \\
Crude fibre (\%) & 1.38 \\
Total ash (\%) & 10.29 \\
Nitrogen free extract & 43.17 \\
Metabolisable energy (kcal/100g) & 422.28 \\
\hline
\end{tabular}

Warris (2000) reported that thiobarbituric acid values raise above $1 \mathrm{mg} \mathrm{MA} / \mathrm{kg}$ indicate unacceptable level of oxidative rancidity in fresh meat. The marginal increasing thiobarbituric acid level of the pet food could be due to higher dry matter content. The tyrosine value increased significantly $(\mathrm{P}<0.01)$ from 35.53 to $77.36 \mathrm{mg} / 100 \mathrm{~g}$ on storage for 50 days at room temperature (Table 3 ). The results were in agreement with that of Rajkumar et al., 2007, who concluded that the mean tyrosine value of the samples packed in aerobic, vacuum and modified atmosphere increased gradually from the day of packaging up to $21^{\text {st }}$ day of storage. Karthik et al. (2010) reported that the tyrosine

Table 3. Biochemical and microbial quality of pet food during storage at room temperature (Mean \pm S.E.). No of observation $=$ 6 (upto 50 days)

\begin{tabular}{ccccc}
\hline $\begin{array}{c}\text { Storage period } \\
\text { (in days) }\end{array}$ & $\begin{array}{c}\text { TBA } \\
(\mathbf{m g} / \mathbf{k g})\end{array}$ & $\begin{array}{c}\text { TV } \\
(\mathbf{m g} / \mathbf{1 0 0 g})\end{array}$ & $\begin{array}{c}\text { TVC } \\
(\mathbf{l o g} \mathbf{c f u} / \mathbf{g})\end{array}$ & $\begin{array}{c}\text { Yeast and mold } \\
\text { count }(\mathbf{l o g} \text { cfu/g) }\end{array}$ \\
\hline 0 & $0.46^{\mathrm{a}} \pm 0.14$ & $35.53^{\mathrm{a}} \pm 0.01$ & $3.46^{\mathrm{a}} \pm 0.09$ & $\mathrm{ND}$ \\
10 & $0.83^{\mathrm{b}} \pm 0.09$ & $38.66^{\mathrm{b}} \pm 0.02$ & $3.63^{\mathrm{b}} \pm 0.06$ & $\mathrm{ND}$ \\
20 & $1.58^{\mathrm{c}} \pm 0.08$ & $49.50^{\mathrm{c}} \pm 0.05$ & $3.92^{\mathrm{c}} \pm 0.05$ & $\mathrm{ND}$ \\
30 & $1.83^{\mathrm{d}} \pm 0.08$ & $52.46^{\mathrm{d}} \pm 0.05$ & $4.09^{\mathrm{d}} \pm 0.05$ & $\mathrm{ND}$ \\
40 & $2.19^{\mathrm{e}} \pm 0.07$ & $63.43^{\mathrm{e}} \pm 0.01$ & $4.56^{\mathrm{e}} \pm 0.15$ & $\mathrm{ND}$ \\
50 & $2.52^{\mathrm{f}} \pm 0.03$ & $77.36^{\mathrm{f}} \pm 0.02$ & $5.90^{\mathrm{f}} \pm 0.29$ & $\mathrm{ND}$ \\
\hline
\end{tabular}

Means bearing different superscripts differ significantly $(\mathrm{P}<0.01)$ between storage period $\mathrm{n}=2$; TVC: Total viable count MA: Malonaldehyde

Anandh and Jagatheesan (2012) who reported that moisture, protein, fat and ash content of poultry byproduct meal were $8 \%, 66 \%, 18 \%$ and $1.8 \%$, respectively which make it favourable for pet food formulation. According to Wani et al (2011) and Abul-fadl (2012) dried Cauliflower leaf, upper stem and leaf mid rib powder had considerable amount of amino acid especially glutamic acid, aspartic acid and alanine, fair amount of $\beta$ carotene, Iron, Copper, Manganese and Zinc. The proximate composition (\%) viz., crude protein, ether extract, crude fibre, total ash, nitrogen free extract and metabolizable energy ( $\mathrm{K}$ $\mathrm{Cal} / 100 \mathrm{~g}$ ) of prepared pet food on dry matter basis were 26.63, 18.52, 1.38, 10.29, 43.17 and 422.28, respectively were presented in Table 2 . The nutrient composition of the pet food was in accordance with the NRC standards (2006) of 6-10\% moisture, 16-30\% protein, 7-20\% fat, 41-70\% carbohydrate and 2800$4050 \mathrm{~K} \mathrm{Cal} / \mathrm{kg}$ metabolisable energy (as feed basis).

The thiobarbituric acid value increased significantly $(\mathrm{P}<0.01)$ from 0.46 to $2.52 \mathrm{mg} \mathrm{MA} / \mathrm{kg}$ on storage up to 50 days at room temperature (Table 3 ). The results are in congruent with the studies made by Karthik et al. (2010) where the thiobarbituric acid value of the pet food increased significantly $(\mathrm{P}<0.01)$ from $0.41 \mathrm{mg}$ to $2.52 \mathrm{mg} / \mathrm{kg}$ on storage for 5 days at room temperature. values expressed as $\mathrm{mg} / 100 \mathrm{~g}$ increased significantly $(\mathrm{P}<0.01)$ from $42.42 \mathrm{mg}$ to $76.00 \mathrm{mg} / 100 \mathrm{~g}$ during the storage period.

The total viable count increased significantly $(\mathrm{P}<0.01)$ from $\log 3.46$ to $5.90 \mathrm{cfu} / \mathrm{g}$ on storage up to 50 days at room temperature (Table 3). Fischer et al. (2007) reported that even if dry extruded pet food was poor substrate for microbial development steady increase in microbial count could be due to post processing/ handling contamination. Yeast and mold count was not detected up to 50 days storage (Table 3). Hence the thiobarbituric acid value, tyrosine value, total viable count and yeast and mould count indicate the safety level of the pet food for consumption.

Acceptability by pet: Acceptability studies were conducted for the continuous period of 5 days for each pet. Mean score for accepting the pet food subsequent times, influence on food intake and digestive disturbance were $0.67,0.80$ and 0.90 respectively. No digestive disturbance occurred and improvement in food intake was noticed $80 \%$ of the pets fed with pet food.

The pet food that was prepared by incorporation of 35 $\%$ chicken head $(20 \%)$ and feet meal $(15 \%)$ and $10 \%$ cauliflower waste meal were evaluated for appearance, consistency, odour by the pet owner and their mean 
score were 6.60, 5.07 and 6.07, respectively and was readily accepted by the pet dogs.

\section{Conclusion}

A pet food prepared by assimilating $20 \%$ chicken head, $15 \%$ chicken feet meal and $10 \%$ cauliflower waste meal had better appearance, odour, rich in protein \& fat, no allergic reactions/like digestive disturbances in pet dogs during feeding and the acceptability was very high even on storage in LDPE bags at room temperature up to 50 days. The pet food acceptability studies revealed that even though the TBA value, Tyrosine value and microbial count increased consistently, they are within the acceptable levels. Hence it could be concluded that a pet food with good acceptability to dogs can be prepared by incorporating $35 \%$ poultry by-product meal viz chicken head $(20 \%)$ and feet $(15 \%)$ and $10 \%$ cruciferous vegetable by-product meal using minimum low cost equipment and simple, easily adoptable technique. Hence, the manufacture and marketing of the pet food can be undertaken by any entrepreneurs without much capital investment, thereby providing self-employment opportunities to women self help groups, unemployed rural youth, school drop outs etc. Economic utilization of poultry slaughterhouse by-products for the preparation of value added pet food also alleviates the environmental pollution health hazards and problems. The pet food developed in par with the recommendations of the NRC (2006) provides a nutritionally complete planned food for the pets.

\section{REFERENCES}

AAFCO (2008). Official publication of the Association of American Feed Control Officials. Inc., Atlanta..

Abul-fadl, M. M. (2012). Nutritional and chemical evaluation of white cauliflower by-products flour and the effect of its addition on beef sausage quality. Journal of Applied Sciences Research, 8(2): 693-704

Anandh, A. and Jagatheesan, R. (2012). Technologies for effective disposal of dead poultry carcasses. Poultry Line, 12(5):59-62

AOAC (1995). Official Methods of Analysis.16th ed. Association of Official Analytical Chemist. Int., Arlington, VA.

APHA (American Public Health Association), (1984). Compendium of methods for the microbiolgical examination of foods, $2^{\text {nd }} \operatorname{Edn}(\mathrm{Ed})$ M. L. Speck. American Public Health Association, Washington, DC..

Fischer, A. R., De Jong, A. E., Van Asselt, E. D., De Jonge,
R., Frewer, L. J. and Nauta, M. J., (2007). Food safety in the domestic environment. An interdisciplinary investigation of microbial hazards during food preparation, Risk Analysis, 27: 1065-1082

Food and Agricultural Organisation (FAOSTAT), (2011).www.faostat.fao.org

ICMSF, Microorganisms in foods sampling for microbiological analysis: Principles and specific applications, Second edition, Blackwell 1986, Pp. 158

Karthik, P., Kulkarni, V. V. and Siva Kumar, K., (2010). Preparation, storage stability and palatability of spent hen meal based pet food. Journal of Meat Science, 47: 330-334

Karthikeyan, N., (2000). Processing, packing and shelf-life evaluation of pet food from poultry by-products. M. V. Sc., Thesis submitted to the Indian Veterinary Research Institute, Deemed University, Izatnagar.

Karthikeyan, N., (2004). Effect of processing methods on nutritional quality and storage stability of poultry by-product meal based pet foods. Ph.D., thesis submitted to the Indian Veterinary Research Institute, Deemed University, Izatnagar.

National Research Council (2006). The nutrient requirements of dogs and cats national academic press. Washington, USA..

Ponmani, V., (1997). Studies on the preparation of dog chew and evaluation of its shelf-life. M. V. Sc thesis submitted to Tamil Nadu Veterinary and Animal Sciences University, Chennai-600 051 .

RajKumar, V., Narendra babu, R., Dushyanthan, K., Ezhivelan, S. and Venkataramanujam, V., (2007). Heritage Indian meat products. Processed Food Industry, 11(34): 43-49

Singh R. P., (2012). XXIX Annual Conference in National Symposium of Indian Poultry Science Association 2012, On commercial and rural poultry production: Novel concepts and strategies to meet growing demand and changing consumer needs, IPSACON Souvenir, $1: 111-115$

Snedecor George, W. and Cochran William, G (1989). Statistical Methods, Eighth Edition, Iowa State University Press..

Strange, E. D., Benedict, R. C., Smith, J. C. and Swift, C. E., (1977). Evaluation of rapid tests for monitoring alterations in meat during storage. Journal of Food Protection, 40: $843-844$

Wani, T. A., Monika, S. and Raj Kumari, K., (2011). Nutritional and sensory properties of roasted wheat noodles supplemented with Cauliflower leaf powder. Annals. Journal of Food Science and Technology, Article in press, 102-107

Warris, P. D., (2000). Meat science an Introductory text, Cabi publishing, United Kingdom, Pp. 52. 